\title{
Assessment of Energy Intensity Indicators in Libya: Case Study
}

\author{
Wedad El-Osta ${ }^{1} \&$ Usama Elghawi $^{2}$ \\ ${ }^{1}$ Center for Solar Energy Research and Studies, Tripoli, Libya \\ ${ }^{2}$ Libyan Atomic Energy Establishment, Tripoli, Libya \\ Correspondence: Wedad El-Osta, Center for Solar Energy Research and Studies, P.O. Box 12932, Tripoli, Libya. \\ Tel: 218-926-765-839. E-mail: e_wedad@hotmail.com
}

Received: February 28, 2020 Accepted: March 11, 2020 Online Published: March 26, 2020

\begin{abstract}
Energy-efficient technologies provide chances for money savings and reducing environmental damages related to energy use. This paper aims to assess the energy efficiency in Libya and tools to promote its implementation. In addition, it seeks to present measures and programs that could be foreseen in the transformation sector and some end users.

Data of energy intensity in Libya was taken from different recognized sources such as World Development Indicators (WDI) - World Bank, and Enerdata web site. The data was collected, assembled, and analyzed using Ms Excel sheets. Results were plotted and compared to World average and Africa or with (Middle East and North African) MENA countries where ever data is available. The main indicators over almost quarter of a century (19902014) were presented and changes over this period were indicated.

It could be concluded that primary energy intensity for Libya during (2000-2014) is comparable to world average values and for Africa and the final energy intensity has increased at only $0.7 \%$ per year during the same period. As an oil producer and exporter country, the ratio of final enrgy intensity to primary energy intensity in Libya has increased at a rate of $1.1 \%$ during (2000-2014), which is greater than the World average and African countries. The rate of energy intensity of transport has increased by $6.9 \%$ per year for the period (1990-2014) and $7.8 \%$ per year for the period (2000-2014) compared to the world improvement (-1.8\%) per year and for Africa $(-0.3) \%$ per year for the period (2000-2014)). This is due to lack of regulations and measures concerning this sector and increased number of private cars. Suitable measures and policies should be taken towards this sector to improve its performance since it contributes to the highest share of energy consumption. The highest share of electric energy consumption is at residential, then commercial and service end use, followed by street lighting. There is a good potential for energy saving at these sectors.
\end{abstract}

Keywords: energy efficiency indicators, energy intensity, primary energy intensity, final energy intensity, $\mathrm{CO}_{2}$ emission indicators

\section{Introduction}

Global energy consumption in 2018 has increased by $2.3 \%$, which is twice that of 2010 due economy as well as heating, and cooling energy demand growth, which had led to $\mathrm{CO}_{2}$ increase of 1.7\% [IEA, Global Energy and $\mathrm{CO}_{2}$ Status Report-2019]. In buildings, the global final energy consumption has increased by about 5\% during (20102017), while electricity consumption faced largest growth of 15\% since 2010 [IEA, 2018 Global Status Report, Towards a Zero emission, efficient and resilient buildings and construction sector].

Libya is in transition phase of development for its infrastructure growth, including development of the energy sector. The total final energy demand in Libya had grew from 4.2 tons of oil equivalent (Mtoe) in 1980 to 10.6 Mtoe in 2006. The electric energy demand had more than doubled in ten years; from 0.3 Mtoe in 1980 to 0.6 Mtoe in 1990 and has been four folds from 1980 to 2000 (1.1 Mtoe) and six folds from 1980 to 2006 and it is expected to grow to 5.59 Mtoe by 2030 (Fragkos et al. 2012). This demand could be met either by increase of supply or improving the efficiency of energy supply and end use. Energy-efficient technologies could offer solutions and could reduce environmental impacts associated with recent energy systems use.

Today, many countries are implementing initiatives that aims promoting more efficient use of energy. Energy efficiency (EE) is defined, according to (Sauma et al. 2016), as a set of actions that optimizes the relationship between the amount of energy consumed and the quantity of final products and services obtained. IEA defined energy efficiency as the quickest and least cost way of encouraging and maintaining energy security, 
environmental sustainability and economic challenges. It developed its 25-policy recommendation in 2008, which was updated in 2011 (IEA $25 \mathrm{EE}$ recommendation, 2011). Energy conservation and efficiency measures are the most cost-effective tools of minimizing the energy consumption. In addition, they are one of the best ways to satisfy energy demand with lowest cost. For this reason, energy conservation and energy efficiency are the key components of any national energy policy.

Energy efficiency improvements since 1970s in the 11 IEA member countries saved 56 EJ or 1337 tons of oil equivalent in 2011. These savings accounted for 59\% of total fuel consumption TFC of these member countries that year (IEA 2014a). Global Institute recently reported that efforts to improve energy productivity could cut worldwide energy demand growth by more than half between now and 2020, totaling 142 EJ of avoided annual energy demand (CGED, 2007). The IEA estimated that if energy efficiency is implemented globally without any delay it could save 7.6 Giga tons (Gt) $\mathrm{CO}_{2} /$ year by 2030. In 2010, this corresponded to energy savings of more than $82 \mathrm{EJ} /$ year by 2030 , or $17 \%$ of the current annual worldwide energy consumption (IEA, 2011). On the other hand, the world energy saving in 2016 compared to year 2000 is $12 \%$ by improvements of energy efficiency (IEA EE 2017 Market report).

Improvements in energy efficiency over the past three decades have played a key role in limiting global increase in energy use and $\mathrm{CO}_{2}$ emissions. For IEA countries, energy efficiency gains since 1990 have led to annual energy savings of more than $16 \mathrm{EJ}$ in 2005 and $1.3 \mathrm{Gt}$ of avoided $\mathrm{CO}_{2}$ emissions. In industry alone, the application of proven technologies and best practices on a global scale could save between $1.9 \mathrm{Gt}$ and $3.2 \mathrm{Gt}$ of $\mathrm{CO}_{2}$ emissions per year. In public power generation, if all countries produced electricity at current best practice levels, $\mathrm{CO}_{2}$ savings would be between $1.8 \mathrm{Gt}$ and $2.5 \mathrm{Gt}$ (IEA, 2014b).

With all these benefits of energy efficiency, should be promoted at all end use sectors on the national level and a national energy action plan should be devised. It should be given more attention in education, at least as elective courses at universities, graduate studies and students' graduation projects. If it was implemented it would had alleviated the recent energy problems and will reduce local environmental impacts. It would create jobs and lead to employment opportunities.

This paper aims to assess the energy efficiency in Libya and to promote its implementation as well as measures and programs that could be foreseen in transformation sector and some end users.

\section{Libya Energy Status or Profile}

With growing concerns about the global environment, energy security and other related issues, energy efficiency is attracting many nations and became their best choice. That is why it is so important to balance what the World Energy Council (WEC) defines as the energy trilemma. WEC in its report 2015 Trilemma Index quantifies the energy trilemma and relatively ranks world countries in terms of their ability to provide a secure, affordable, and environmentally sustainable energy system. Energy performance indicators consider supply, demand, affordability of and access to energy, and the environmental impact of a country's energy use. The related indicators consider the energy performance of these countries including political, social and economic strength and stability. The overall Index performance of 130 countries was assessed in 2015. Libya was ranked 120 in year (2015) with an overall score of (CCD) according to this report (World Energy Council report, 2015). Improvement of this score necessitate the improvement of the energy system and its performance in the first place. Also, Arab Future Energy Index (AFEX) Energy Efficiency, 2017 (AFEX, 2017) results showed that Libya is at the end list of Arab countries, its score was 18\%. AFEX EE 2017 provide assessment of countries progress in energy efficiency according to four evaluation categories: energy pricing, policy framework, institutional capacity and utility. Under these categories, countries are assessed according to 9 different factors and 30 quantitative and qualitative indicators (AFEX, 2017). These indications calls for quick action to promote energy efficiency measures and programs in Libya.

\subsection{Oil and Natural Gas}

Libya's economy is heavily dependent on hydrocarbon production. According to the International Monetary Fund (IMF), oil and natural gas accounted for nearly $96 \%$ of total government revenue and $98 \%$ of export revenue in 2012. In 2013 and 2014, Libya experienced major swings in its oil production, falling to 0.2 million barrels per day (bbl. /d) at the end of 2013. Oil production had improved at the end of the year 2016, where it had reached 0.7 million barrels per day (bbl. /d) and by the middle of 2017 it reached a million barrels per day (bbl. /d) and today in 2019 it is 1.3 million barrels per day (bbl. /d). 
Libya had proved crude oil reserves of 48 billion barrels as in January 2014, according to the Oil and Gas Journal (OGJ), which is the largest reserve in Africa. It is accounting for $38 \%$ for the African continent, and the ninthlargest amount globally (World atlas, 2014).

Before 2011, Libya had been producing an estimated 1.65 million (bbl. /d) of high-quality oil. Almost, $70 \%$ to $80 \%$ of Libya's crude oil is exported to Europe. In 2013, about 75\% of Libya's crude oil was exported to Europe mainly to Italy, Germany, and France.

Libya's natural gas industry recovered in 2012, but its production still below the level of 2011 . About $50 \%$ of natural gas production is exported to Italy. According to OGJ, in January 2014, the estimated Libya's proved natural gas reserves were about 55 trillion cubic feet, which makes it the fifth-largest natural gas reserve holder in Africa.

\subsubsection{Primary Energy Consumption}

The primary energy consumption has grew by one third during one decade (2000-2011) while natural gas has been reduced by almost one third, as shown in Figure 1, (RECREEE, 2012).
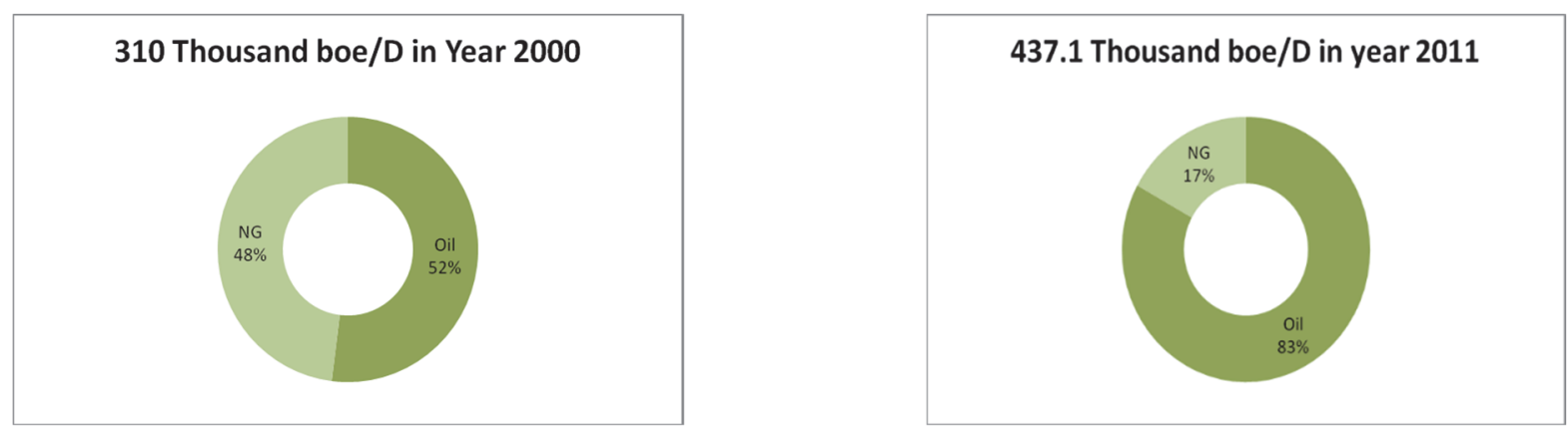

Figure 1. Primary Energy consumption of Libya

\subsubsection{Final Energy Consumption}

Fossil fuel represented $99.11 \%$ of energy consumption in 2014. The total final energy consumption (TFEC) had experienced a fluctuation during last few years. The maximum value of TFEC was near $420000 \mathrm{TJ}$ in 2010 and its lowest value in 2011 was about $290000 \mathrm{TJ}$, according to World bank indicator development and it was $361006 \mathrm{TJ}$ in 2014 (WDI, 2015). The distribution of the final energy consumption is shown in Figure 2, where electricity consumption represented 18\% of final energy demand in 2009 (RECREEE, 2013).

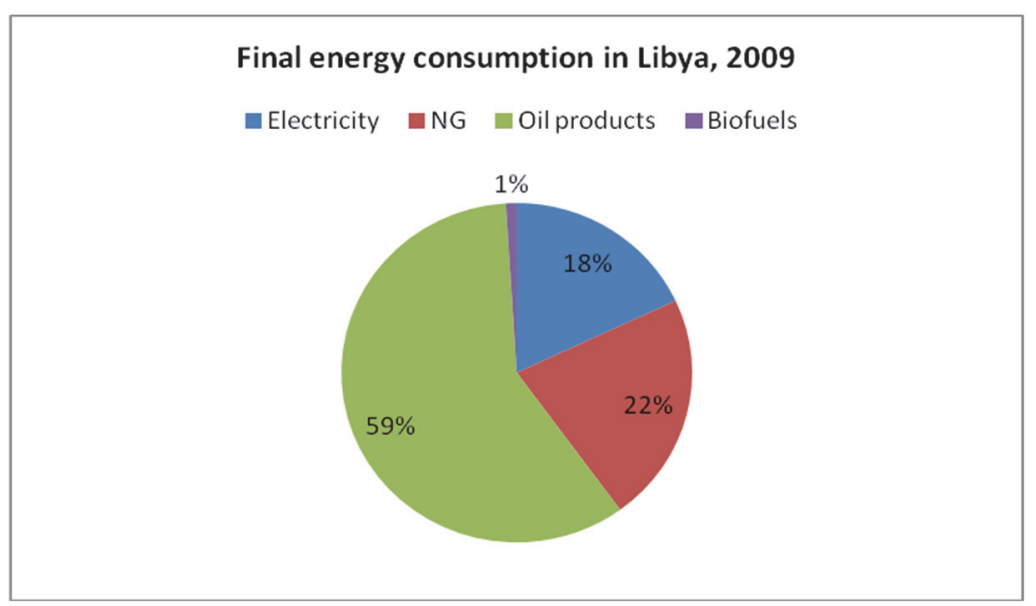

Figure 2. Final Energy consumption of Libya

\subsection{Electric Energy System}

Libya enjoys a well-developed electric network that provides $100 \%$ of the Libyan population and has connections with eastern and western neighboring countries. The General Electricity Company of Libya (GECoL) is a 100\% 
state owned company, which was established in 1984, the company is under the Ministry of Electricity and Renewable Energies. It is a state owned vertically structured power utility with a monopoly over generation, transmission and distribution.

Power generation installations in Libya are steam turbine, gas turbine, diesel, and combined cycles. Energy is generated by 15 power plants - most of them are located along the coastal side of Libya, were the $85 \%$ of population. The plants are: (5) gas power plants, (5) steam power plants and (5) combined cycle power plants. Figure 3, shows the existing power plants.

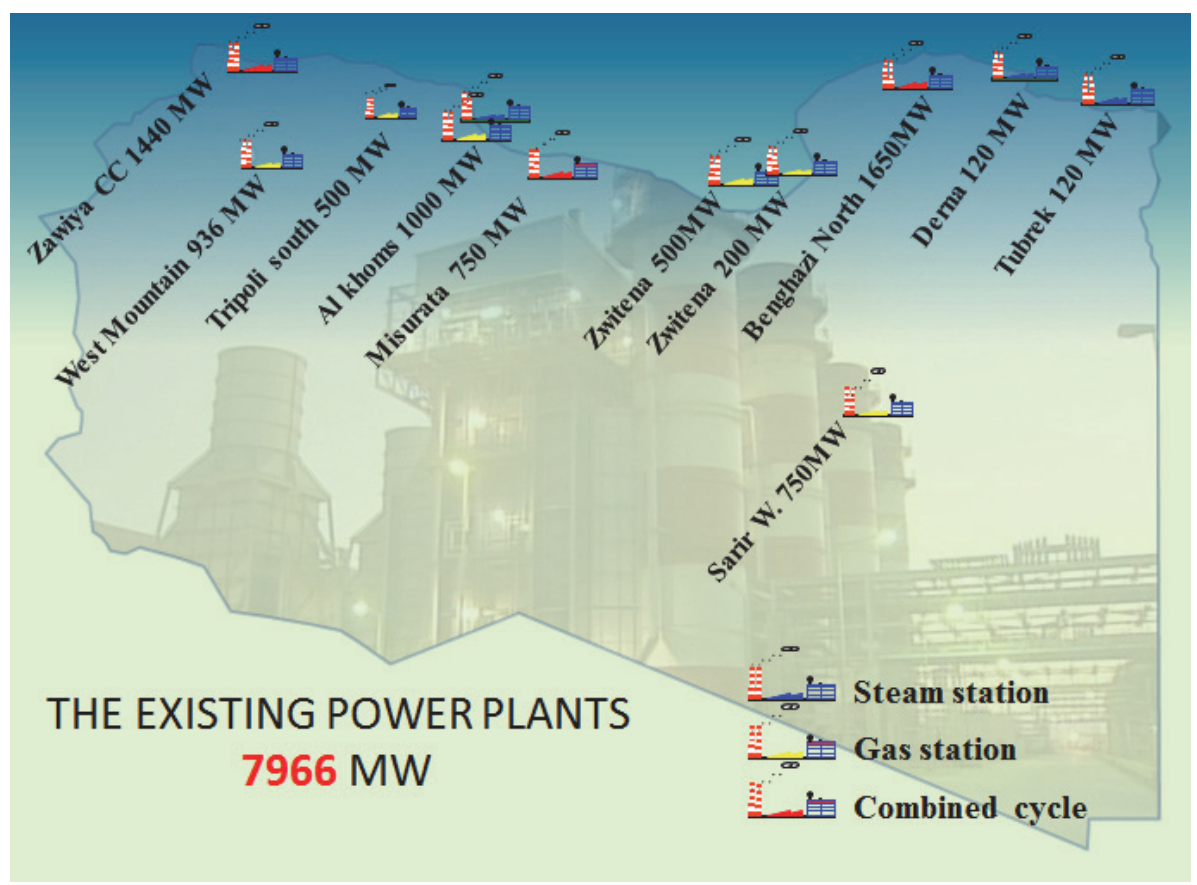

Figure 3. The existing power plants in Libya (Elwerfelli 2015)

Gas turbine (GT) installations are increasingly used in many parts of the world. The installed generating capacity in Libya during 2014 was $7966 \mathrm{MW}$ of energy, of which (43\%) was produced by simple cycle combustion turbines equal to $3425 \mathrm{MW},(44 \%)$ by combined cycle combustion turbines, and (13\%) by steam turbines, as shown in Figure 4. In Figure 5 the type of fuel used for energy generation in year 2014.

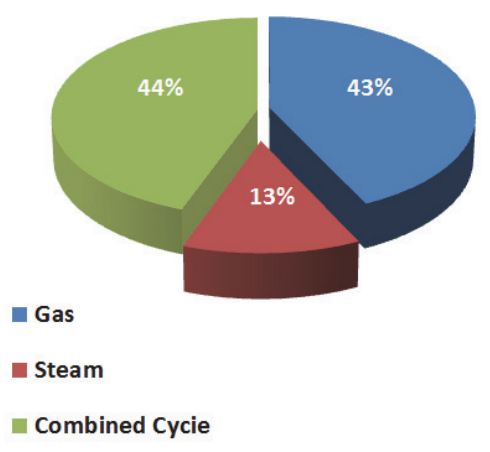

Figure 4. Energy Generation in 2014.

(Elwerfelli 2015)

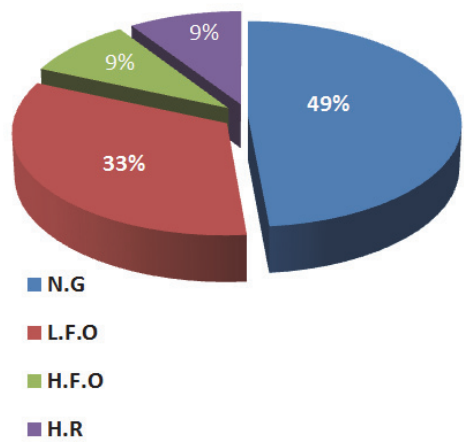

Figure 5. Type of fuel used for energy generation

Because of unforeseen national events, GECoL faced a shortage in the energy production process, which led to 1200 MW load shedding (20\% of total peak load). Energy demand has risen rapidly in Libya over the last decade and high peak demand has led to many blackouts. Currently, peak load is growing at an average annual rate of 
about $10 \%$, which constitutes a great challenge for Libya's power sector. Since gas turbines are quickly installed and the prime cost of such plants is much lower than that of other types of plants for generating peak-load electricity, gas-turbine power stations are popular. They are particularly suitable for this duty as they can be brought up to full power in only a few minutes. In oil and gas producing countries, as in Libya where fuel costs are still well below the world market level, gas turbines are also employed in shift-operated and base-load stations.

In previous study on simple cycle GT in the south Tripoli, power plants showed that high midday ambient temperatures during the summer could cause a $20 \%$ decrease in system capacity (Elghawi and El-Osta, 2015). This means $685 \mathrm{MW}$ energy losses are incurred due to high temperature during summer in these power plants, for all natural gas turbine units having a combined capacity of $3425 \mathrm{MW}$ loss in summer when the temperature reached to $40^{\circ} \mathrm{C}$.

With this amount of GT capacities in Libya, it is worthwhile to investigate the performance of GT under Libyan summer climate conditions, and study the possibilities of integrating the GT with heat recovery steam generator (HRSG) for both power generation and process heat, e.g. thermal vapor compression (TVC), desalination system as an example.

It is the same problem was faced in many areas in Middle East and North African (MENA) countries. The turbines experience a $24 \%$ decrease in system capacity during the summer due to ambient air temperatures up to $45^{\circ} \mathrm{C}$ and higher in Saudi Arabia (Al-Ibrahim \& Varnham, 2010). Ameri \& Hejazi, (2004) estimated that approximately $1900 \mathrm{MW}$ energy losses are incurred due to high temperature in summer in Iran, for 170 natural gas turbine units having a combined capacity of $9500 \mathrm{MW}$. Total electricity generated by gas turbine plants in Egypt is about 7001 MW from different gas turbine models and capacities varying from $25 \mathrm{MW}$ to $260 \mathrm{MW}$. On hot days in summer, the ambient temperature reaches $40^{\circ} \mathrm{C}$ and the gas turbine power output decreases by $18 \%$ from rated capacity, leading to total power lost from gas turbine plants of about $1440 \mathrm{MW}$ while the electric load increases to maximum due to air conditioning and ventilation (Marzouk \& Hanafi, 2013).

\subsubsection{Distribution of Electric Energy Consumption}

The electric energy generated in 2012 classified sector wise is shown in Figure 6. As it could be noticed that the domestic consumption is the highest. It represented more than one third (36\%) of total electric energy consumption in 2012 (GECoL 2012). It is followed by the commercial and street lighting (14\%), then public service (13\%), agriculture (12\%) and industry (11\%). It could be noticed that street lighting consumption is above international standards and appropriate measures should be taken towards this sector to save energy with the use of new technologies that can save up $80 \%$.

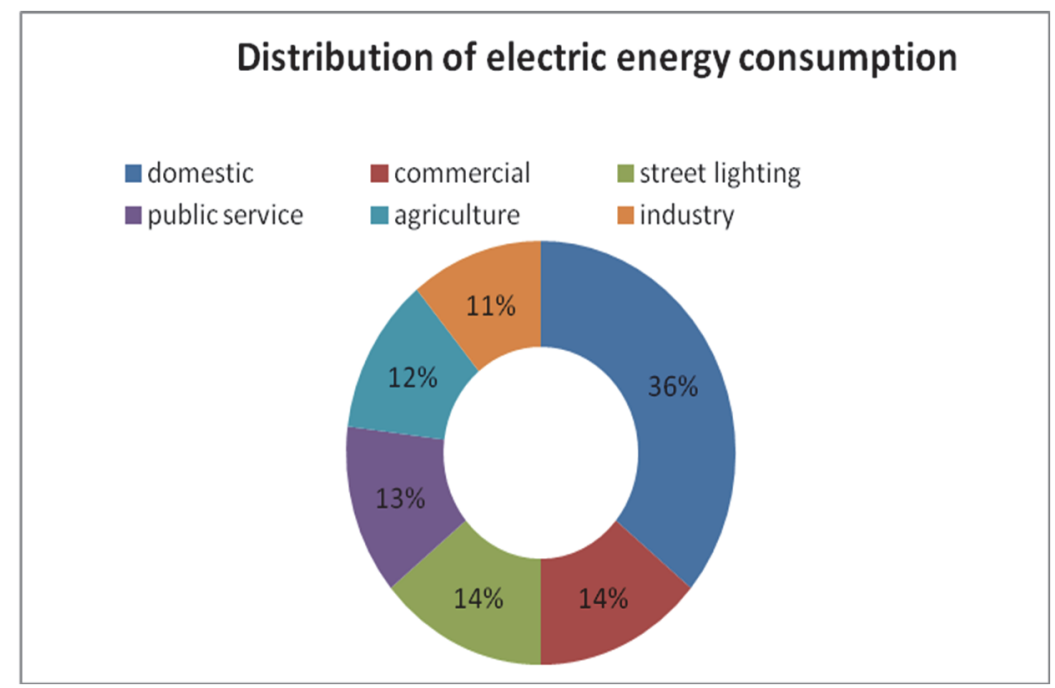

Figure 6. Distribution of electric energy consumption in Libya in 2012

\subsubsection{Performance of Transformation Sector in Libya}

The thermal efficiency of power plants has improved significantly during $2000-2014$ from $25 \%$ to almost $42 \%$, as shown in Figure 7. The transmission and distribution losses (technical and non-technical or commercial) of power generation in Libya have dropped from about 24\% in 2001 to about 13\% during 2002- 2012, according to World 
Development Indicators (WDI), except for year 2006 where it was only $10 \%$ or almost comparable to international standards (WDI, 2015). So additional efforts are needed to reduce these losses.

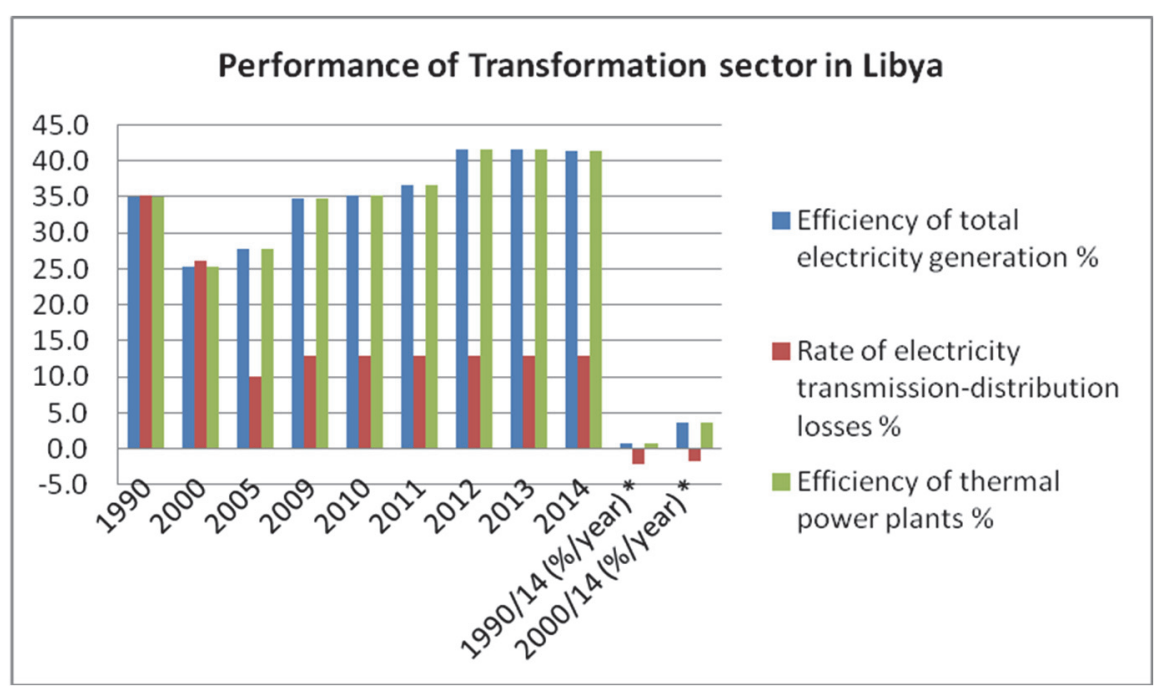

Figure 7. Performance of transformation sector in Libya

Figure 7 shows the performance of the transformation sector, such as: the rate of transmission and distribution losses, the efficiency of the thermal power plants and the total efficiency of the electricity generation. It could be noticed that the efficiency of the electricity generation had improved during the last fifteen years.

\section{Methodology}

Interest in energy efficiency has increased due to concerns about local, regional and global environmental impacts of energy use in addition to other reasons and concerns. The main objective of energy intensity indicators is to measure the activity intensity over a period in order to track the overall performance and compare it with regional and international indicators. The benefit of energy efficiency indicators is to track the energy intensity in the national energy system and the changes over the years. It helps identifying barriers to energy intensity reduction and outlines programs that could be devised and implemented to reduce it.

There are several frameworks that have been developed to track economy, energy use and indicators that provide an insight to the energy sources and use, which could be helpful for energy planners and policy makers. There are mainly two methods the Laspeyres method and the Log Mean Divisia Index (LMDI) (Nanduri, 1998: Belzer, 2014: UNEP, 2011). The second method is the most known and used by different international reports.

The energy intensity indicators in this paper was presented by major energy end use sector as defined by the different international organizations to the following categories: (1) residential, (2) commercial, (3) industrial, (4) service, and (5) transportation, depending upon data availability and energy transformation sector, as indicated in section 4. These sectors were not disaggregated into further subsectors due to unavailability of data for Libya.

National energy data was provided by the Bureau of Energy Data and Studies, Libyan National Energy Committee. National energy data profile for Libya was published by this office every three years in the World Energy Council (WEC) conferences. The last publication of the National energy data profile was issued in 2006 at the 20th WEC congress 2007. After this date, all national energy data are available as a scattered information from international sources. Since the quality of data and its consistency is an important factor for reliable and meaningful energy efficiency indicators, energy data of this study was taken from reliable international sources as indicated in related sections.

Data of energy intensity in Libya was taken from different sources such as World Bank collection of development indicators (WDI, 2016), (WEC, 2016), and Enerdata web site. The data was collected and compiled from these recognized sources. It was assembled and plotted in figures and compared to World average and Africa or with (Middle East and North African) MENA countries where ever data is available. The base year was taken as 1990 . The changes over almost quarter of a century (1990-2014) were presented and changes over last fourteen years (2000-2014) were indicated. 


\section{Assessment of Energy Efficiency Indicators}

The design, implementation and monitoring of national energy policies requires indicators that reflects energy use and its performance. Energy indicators are important for analyzing different relations of economic and human activity, energy consumption and pollution emissions. These indicators could illustrate for policy makers the areas where energy savings should be implemented. In addition, it provides information concerning energy trends, which could be helpful in estimating future energy demand. Such indicators are crucial for the monitoring and assessment of National Energy Efficiency Action Plans (NEEAPs) for any nation.

Energy intensity is defined as the quantity of energy required to produce one unit of Gross Domestic Product GDP. In addition, it is defined as the amount of energy consumed per activity or output for sub-sectors and end user. Generally energy intensity is calculated as energy consumed divided by an economic indicator. Energy intensity is determined by many factors not just energy efficiency. Such factors can include the structure of the economy, the type of industry base, the exchange rate, and the affordability of energy services, the size of a country, climate and behavior (IEA 2014c). It is considered a good measure of the energy performance of an economy. The use of energy intensities allows countries to set overall targets independent of economic growth or the level of future energy demand.

The following energy efficiency indicators were classified, according to world energy council and Enerdata indicators, to macro and end use indicators.

\subsection{Macro Indicators}

Policy makers to monitor national goals associated to the energy sector can use macro energy indicators. These indicators are devised to measure the impact of national energy policies in terms of strategic, macroeconomic, social and environmental issues.

\subsubsection{Primary Energy Intensity}

Primary energy intensity aims to measure the overall energy efficiency of the economy. It is defined as the primary energy consumption divided by the Gross Domestic Product GDP at constant price. Figure 8-a, shows the primary energy intensity at purchasing power parity in kilo oil equivalent (koe) for Libya during 2000- 2014 compared with Africa and World. It could be noticed that it is comparable to both, world average values and Africa. Its value ranged from $0.107 \mathrm{koe} / \$ 05 \mathrm{p}$ in 1990 to $0.126 \mathrm{koe} / \$ 05 \mathrm{p}$ in 2010 , which was slightly less than Africa and the World. It had increased in 2011 to $0.22 \mathrm{koe} / \$ 05$ due to civil war in Libya then it improved in 2012 and 2013 to 0.136 koe $/ \$ 05 \mathrm{p}$ and $0.151 \mathrm{koe} / \$ 05$ respectively then it increased to $0.213 \mathrm{koe} / \$ 05 \mathrm{p}$ due to political problems that Libya went through in 2014. In general the rate of increase in primary energy intensity during $1990-2014$ is $2.9 \%$ per year and for the period 2000-2014 there is a slight improvement of 2.2\% per year but far behind Africa and world improvement, as shown in Figure 8-b. The relatively high intensity for Libya can be explained primarily by the economic structure, political problems and the lack of major energy efficiency policies and programs.

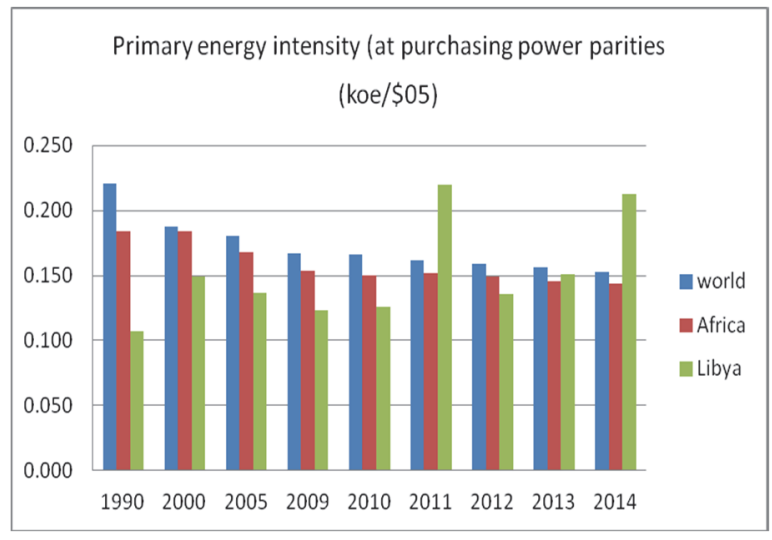

Figure 8-a. Primary energy intensity of Libya to Africa and the World (2000-2014).

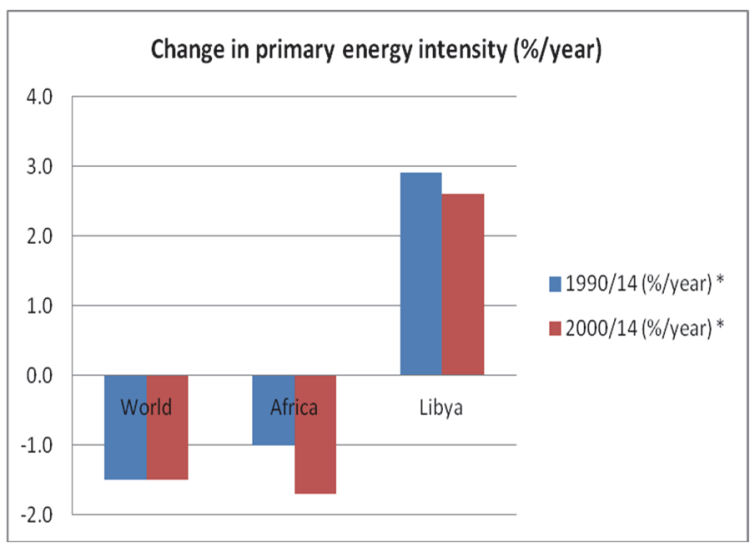

Figure 8-b. Changes in primary energy intensity. compared 


\subsubsection{Final Energy Intensity}

Final energy intensity aims at measuring the efficiency of energy consumption at end use level. Final energy intensity is defined as final energy consumption divided by the GDP at constant price. Figure 9-a, shows the final energy intensity of Libya compared with the average world and Africa for the period of 2000- 2014.

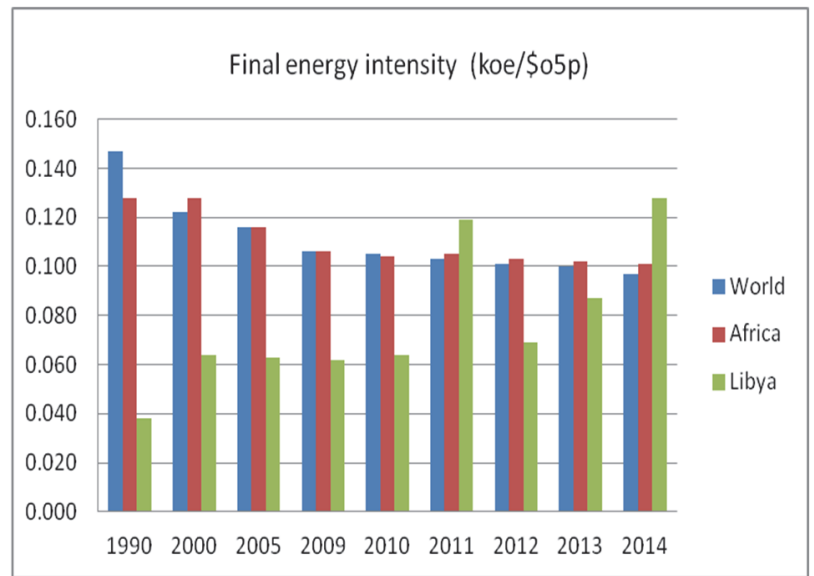

Figure 9-a. Final energy intensity of Libya compared

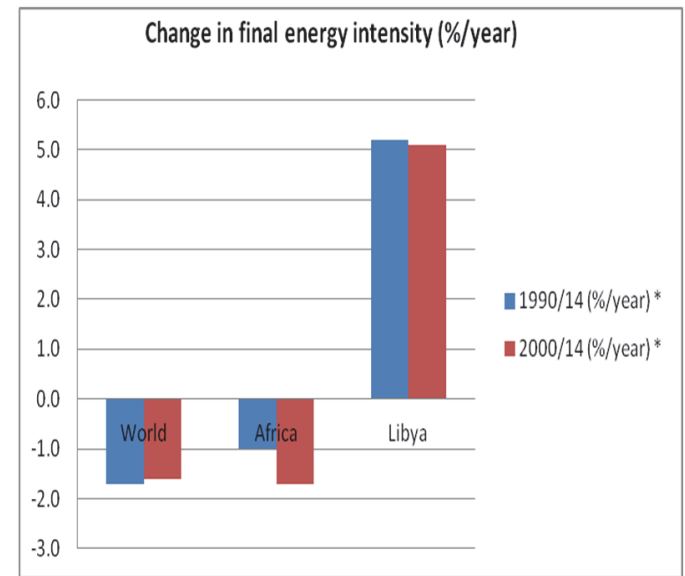

Figure 9-b. Changes in final energy intensity to Africa and the World (2000-2014)

The final energy intensity of Libya has increased from the period of the 1990's to almost constant value during the next 2 decades. It has increased in 2011 due to civil war and in 2014 due to political problems. On average the increase is about $5.2 \%$ per year during $1990-2014$, and $5.1 \%$ per year for the period of $2000-2014$, as depicted in Figure 9-b. There was no improvement in the final energy intensity. It is still high compared to Africa and world average.

\subsubsection{Ratio of Final Energy Intensity to Primary Energy Intensity}

The ratio between final and primary intensities represents the performance of the overall energy transformation sector. Figure 10-a, shows the ratio of final energy intensity to primary energy intensity for Libya compared to world average and Africa. The annual increase of this ratio is $1.1 \%$ during $(2000-2014)$ for Libya compared to $0.0 \%$ in Africa and world average of $(-0.2 \%)$, as shown in Figure 10-b. This is due to the fact that Libya is an oil producer and exporter country.

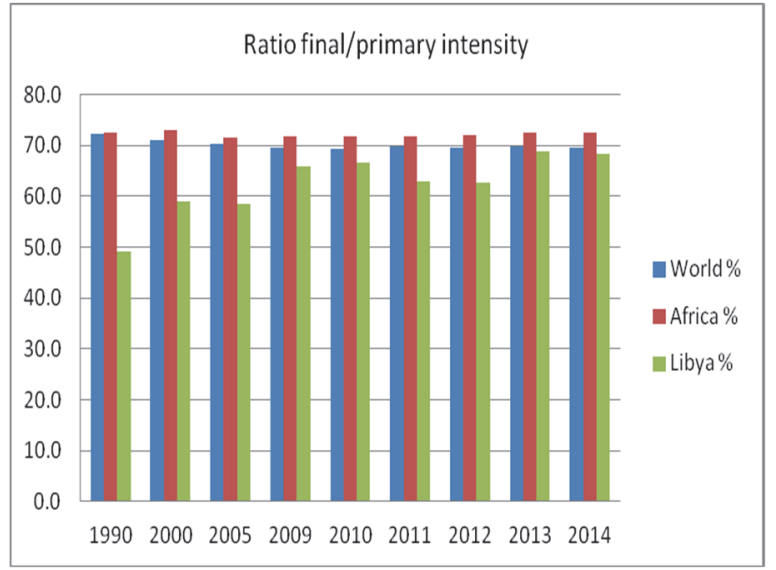

Figure 10-a. Ratio of final energy to primary energy intensity.

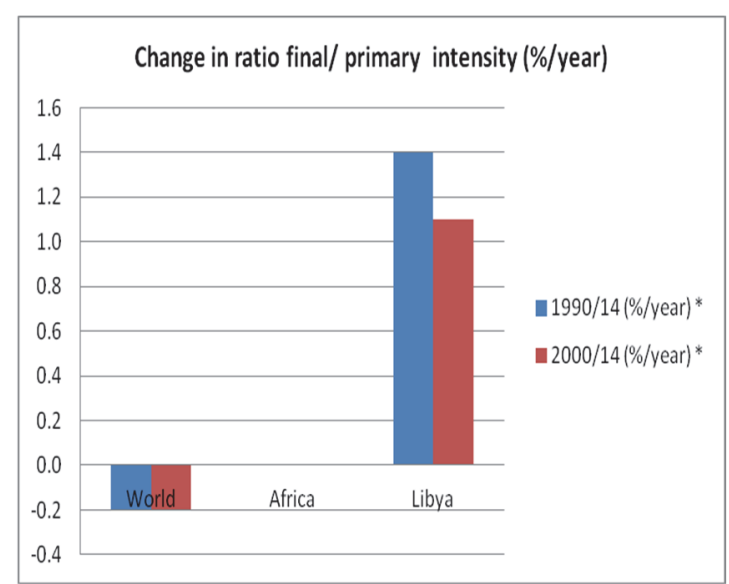

Figure 10-b. Changes in ratio final/primary 


\subsection{4 $\mathrm{CO}_{2}$ Emission Indicators}

At the macro level, two main indicators are assessed:

\subsubsection{1 $\mathrm{CO}_{2}$ Emission/ Capita}

Libya has the highest emissions of $\mathrm{CO} 2$ per capita, which is total quantity of $\mathrm{CO}_{2}$ emissions due to fuel combustion divided by the population (CO2/cap). This is due primarily to the high level of primary energy consumption per capita (more than 3 toe/capita). This figure is high due to high primary energy production compared to population since Libya is an oil producer and exporter. Figure 11, shows the $\mathrm{CO}_{2}$ emissions per capita for Libya compared to world average and Africa during the period of (2000- 2014). $\mathrm{CO}_{2}$ emissions per capita had increased worldwide by an average of $1.1 \%$ per year during above period, $1.2 \%$ per year in Africa and on the other hand it increased only by $0.1 \%$ year in Libya.

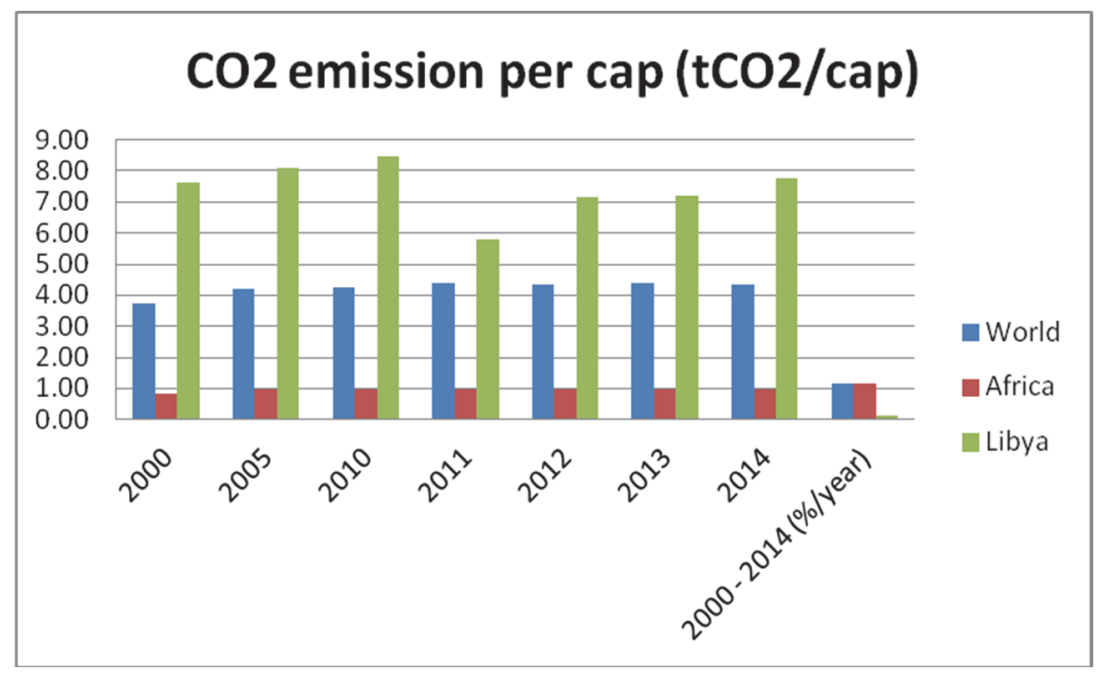

Figure 11. $\mathrm{CO}_{2}$ emissions per capita $\left(\mathrm{tCO}_{2} / \mathrm{cap}\right)$

\subsubsection{2 $\mathrm{CO}_{2}$ Intensity}

The $\mathrm{CO}_{2}$ intensity is defined as total quantity of $\mathrm{CO}_{2}$ emissions due to fuel combustion divided by GDP in \$2005 $\left(\mathrm{CO}_{2} / \$ 05 p\right)$. The $\mathrm{CO}_{2}$ emissions intensity had decreased worldwide during the period (2000-2014). It is decreased by an average of (-1.3) per year for the period 2000-2014, and in Africa by (-1.2) per year for the same period while it had increased by 3.1 per year in Libya, as shown in Figure 12.

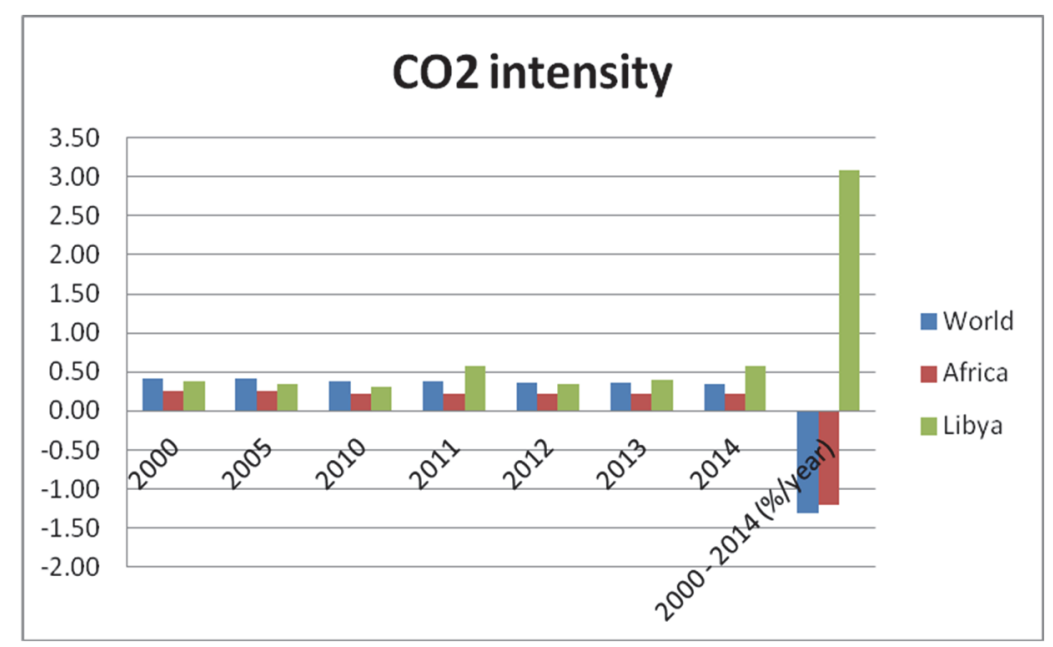

Figure 12. $\mathrm{CO}_{2}$ intensity $\left(\mathrm{kCO}_{2} / \$ 05\right)$ 


\subsection{End Use Indicators}

\subsubsection{Industry}

Figure 13 represents the energy intensity of industry for Libya compared to world average and Africa during the period of (2000- 2014). There is an improvement in the energy intensity since 2005 in Libya as shown in figure 14 but it suddenly increased in 2011 and went back in 2012. The share of electricity production is $100 \%$ for all years.

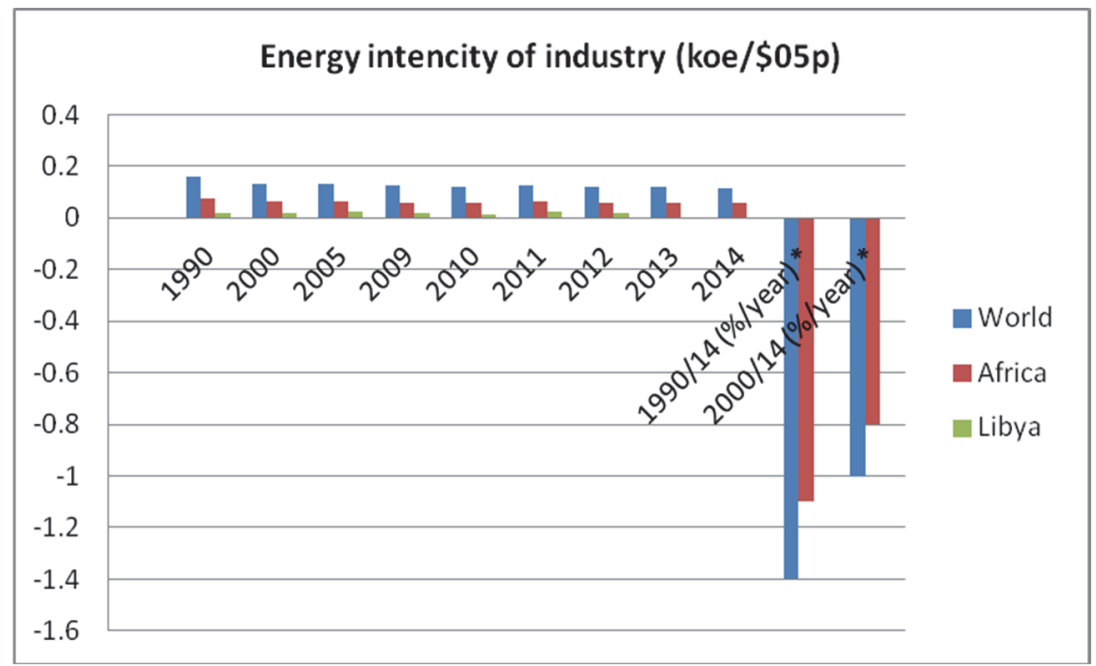

Figure 13. Energy intensity of industry (koe/\$05p)

\subsubsection{Transport}

Transport is the most important energy consumer in Libya with a share of about $59 \%$ of the final energy demand in 2012 (RECREEE, 2013). Annual growth of transport energy consumption between 2000 and 2012 in Libya is $7.4 \%$. This increase is mainly explained by the rapid development of the transportation sector in Libya as a result of various factors such as economic growth, fast urbanization and a large proportion of the population having private cars in the absence of public transport.

The energy intensity of transportation sector in Libya compared to Africa and world intensity is shown in Figure 14-a, and the change in its rate is shown in figure 14-b. The rate of energy intensity of transport has improved on the world scale. It decreased at a rate of $(-1.8 \%)$ per year and for Africa a rate of $(-0.3 \%)$ per year for the period 2000-2014. For Libya, it has increased by $6.9 \%$ per year for the period $1990-2014$ and $7.8 \%$ per year for the period 2000-2014. This is due to lack of regulations and measures concerning this sector and increased number of private cars.

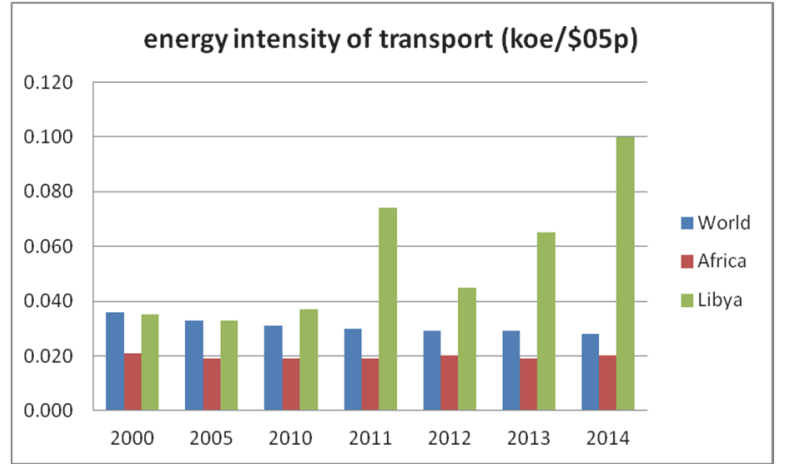

Figure 14-a. Energy intensity of transport (koe/\$05p)

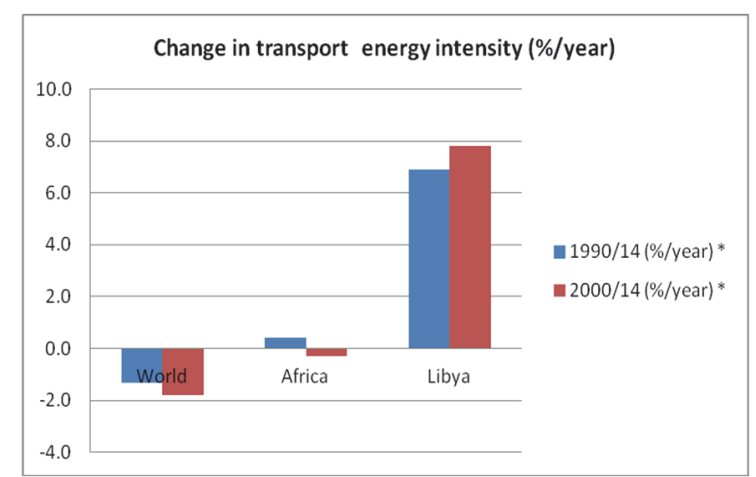

Figure 14-b. Change in transport energy intensity 
The transport $\mathrm{CO}_{2}$ intensity for the world has decreased from $\left.0.09 \mathrm{k} \mathrm{CO}_{2} / \$ 05 \mathrm{p}\right)$ in year 2000 to $0.07 \mathrm{k} \mathrm{CO}_{2} / \$ 05 \mathrm{p}$ in year 2014 at a rate of $(-1.8 \%)$ per year, while for Africa this rate is $(-0.4 \%)$ per year. In Libya, the $\mathrm{CO}_{2}$ intensity in transport sector is much higher than Africa and world average. It has increased from $0.1 \mathrm{k} \mathrm{CO}_{2} / \$ 05 \mathrm{p}$ in 2000 to $0.30 \mathrm{k} \mathrm{CO}_{2} / \$ 05 \mathrm{p}$ in 2014 at a rate of $7.8 \%$ per year for the same period, as shown in Figure 18 . The transport emissions per capita has increased worldwide from $0.79 \mathrm{tCO}_{2} /$ cap in 2000 to $0.86 \mathrm{tCO}_{2} /$ cap in 2014 at a rate of $0.7 \%$ per year while for Africa it has increased from $0.2 \mathrm{tCO}_{2} /$ cap to $0.27 \mathrm{tCO}_{2} /$ cap at a rate of $2.1 \% /$ year for the same period (2000-2014). In Libya it has increased from $2.3 \mathrm{tCO}_{2} / \mathrm{cap}$ to $4.06 \mathrm{tCO}_{2} / \mathrm{cap}$ at a rate of $4.7 \% /$ year for the same period (2000-2014) due to the same previous reasons.

\subsubsection{Residential or Household}

Global energy use in the household sector increased between 1990 and 2005 by $19 \%$ to reach 82 EJ (Worldwide trends in energy use and efficiency, IEA, 2008). There are mainly two indicators to assess energy efficiency in this sector: the average electricity consumption of household per capita $(\mathrm{kWh} / \mathrm{cap})$ and the penetration of renewable energy or the use of Solar Water Heaters $\left(\mathrm{SWH}^{\mathrm{s}} \mathrm{s}\right)\left(\mathrm{m}^{2} / \mathrm{k}\right.$. hab). Since there are no use for SWH's and other renewable energy technologies in Libya, except for limited pilot projects and testing facilities at Center for Solar Energy Research and Studies (CSERS) and related institutes and universities, so the only indicator is the electricity intensity.

\subsubsection{Electricity Intensities}

The electric energy consumption in Libya has increased during the last decade of the last century (1990-2000) but it started to decrease since 2011, as it is shown in Figure 15-a. It could be noticed that the rate of decrease in electricity consumption, during $1990-2000$, is $0.8 \%$ per year, while for the period $2000-2014$, it is $(-2.0 \%)$ per year, as it is shown in figure 15-b. Figure 15-a shows the average electricity consumption of households per capita ( $\mathrm{kWh} / \mathrm{cap}$ ) for Libya compared to the average world and Africa for the period of 2000-2014. As it could be noticed that the consumption in Libya is higher than the world average and much higher than the average African countries. This could be explained mainly by the rapid growth in electricity demand in the residential sector, in line with the increase in the appliance ownership such as air condition AC, information technology devices and other home appliances as well as the big urbanization that happened during last few years. After the onset of hostilities in 2011, the consumption started to decrease due to electricity network as well as power generation problems. The average decrease rate of electricity consumption of households per capita is in Libya is $(-2 \%)$ per year during the period 2000-2014 as shown in Figure 15-b, while the world average increase is 1.6\% per year and in Africa at 3\% per year. Energy efficiency and energy conservation should be the primary solution to solve these problems as well as using distributed generation by renewable energy sources (PV and WECS's) instead of using fossil fuel small generators that are available right now at the market and are used by publics which contributed to noise and environment pollution.

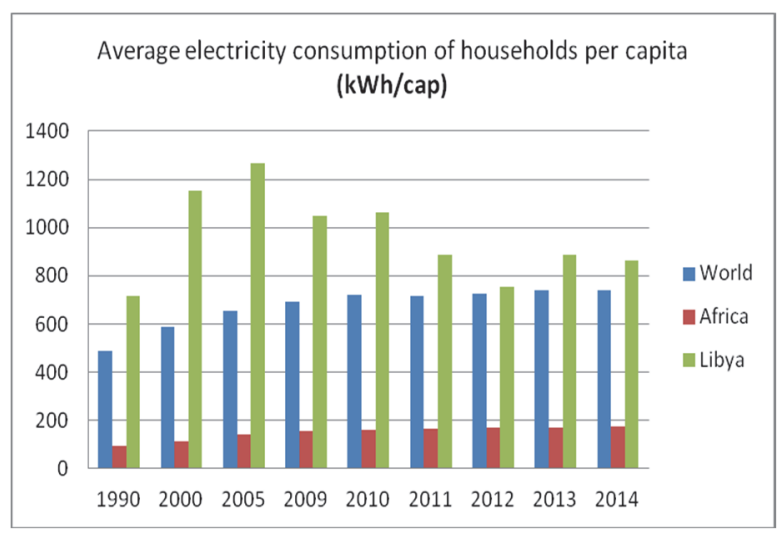

Figure 15-a. Average electricity consumption of households per capita $(\mathrm{kWh} / \mathrm{cap})$. of household.

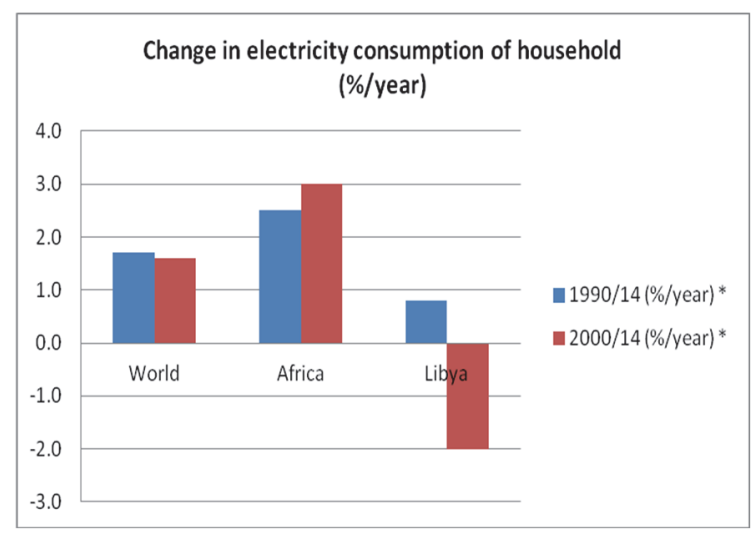

Figure 15-b. Changes in electricity consumption

\subsection{Transformation Sector}

The main indicators in the energy transformation sector are structural indicators and performance indicators. This paper will concentrate on the second indicator. The energy transformation sector in Libya is mainly composed of crude oil refineries and power generation capacities. This paper will concentrate only on the electricity sector. 
Transformation of electrical power production systems in Libya have an efficiency ranging from $35 \%$ to $50 \%$ depending on the power plant, such as simple gas turbines, steam turbines and combined cycles. The assessment of this sector will concentrate on the following parameters due to availability of data, as mentioned briefly, in section 2.2.2.

\subsubsection{Efficiency of Total Electricity Generation}

The efficiency of power generation for Libya compared to the average world and Africa for the period of 20002014 is shown in Figure 16. In Libya between 2000 and 2014, the efficiency has improved from $25.3 \%$ in 2000 to $41.1 \%$ in 2014 , at a rate of $3.6 \%$ per year during this period. The improvement was due to addition of large simple gas turbine and Combined Cycle Gas Turbines (CCGT). In Africa the improvement is 0.4\% per year, where the efficiency of power generation was $40.4 \%$ in year 2000 and $42.9 \%$ in year 2014 . The world average improvement is $0.5 \%$ per year for the same period (2000-2014), where the efficiency of power generation was $38.9 \%$ in year 2000 and $41.5 \%$ in year 2014 .

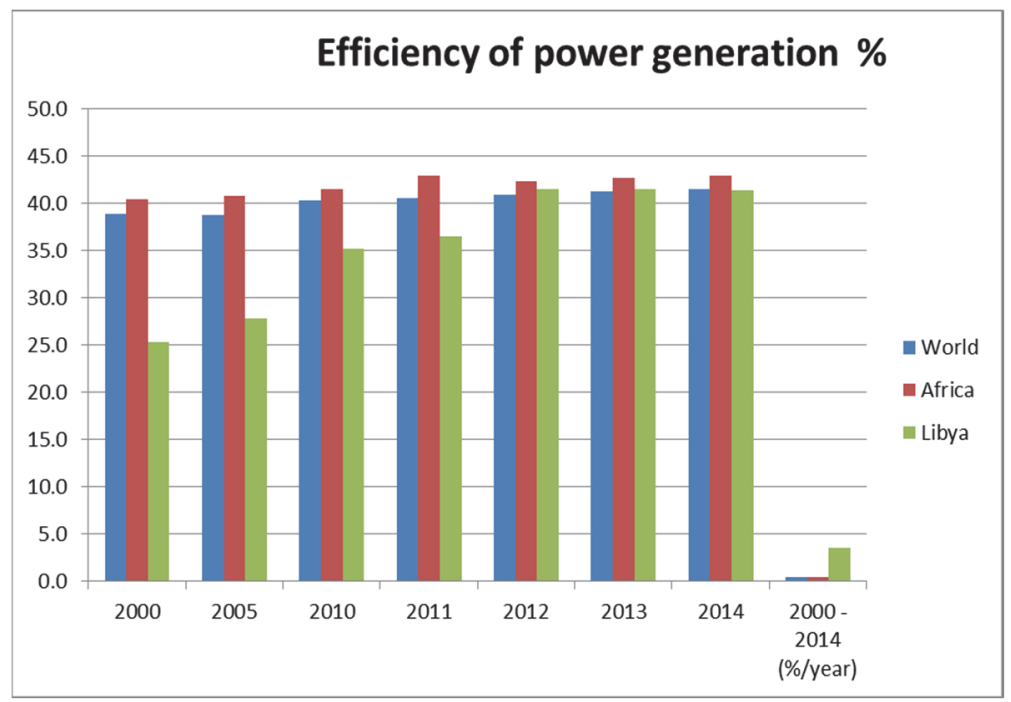

Figure 16. The efficiency of power generation

The efficiency of the energy system varies considerably across Arab States, in MENA region (Middle East and North African), as shown in Figure 17. Efficiency in transformation ranged from 48\% for Egypt, which generate part of electricity by hydropower to $27 \%$ for Bahrain. It is clear that in Gulf Co-operation Council (GCC) the energy loss is higher than North African countries. In Morocco and Tunisia, implementing of renewable energy started few years ago.

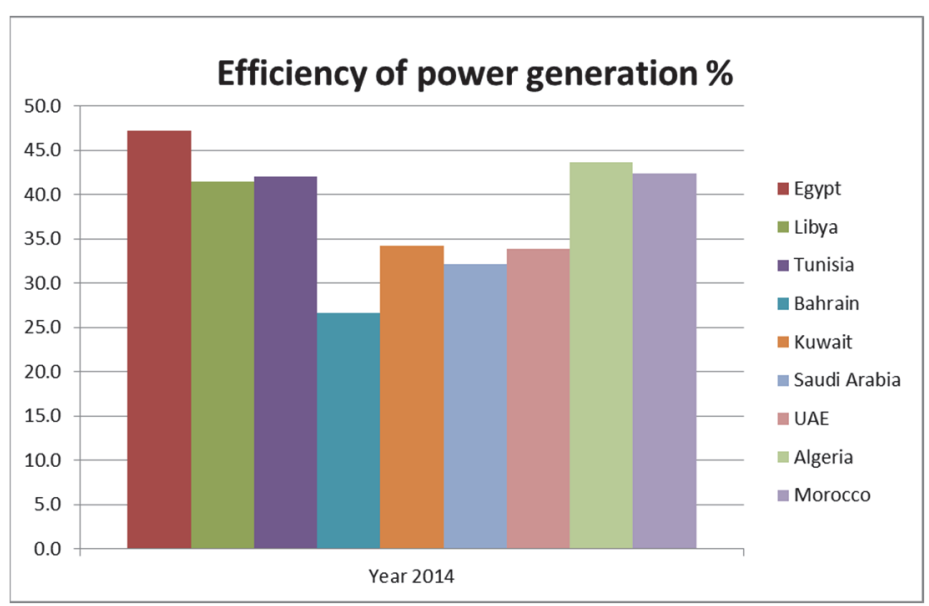

Figure 17. The efficiency of power generation in MENA region 


\subsubsection{Efficiency of Thermal Power Plants}

In Libya the efficiency of thermal power plants improved at a rate of 3.6\% per year during the period (2000-2014) from $25 \%$ to $41.4 \%$, as shown in Figure 18-a. In Africa the improvement was $0.4 \%$ per year, where the efficiency of thermal power plants was $36.0 \%$ in year 2000 and $38.3 \%$ in year 2014. The world average improvement was $0.4 \%$ per year for the same period (2000-2014), where the efficiency of thermal power plants was $34.6 \%$ in year 2000 and $36.4 \%$ in year 2014, as indicated in the previous section. Figure 18-b shows the change in efficacy of thermal power plants per year.

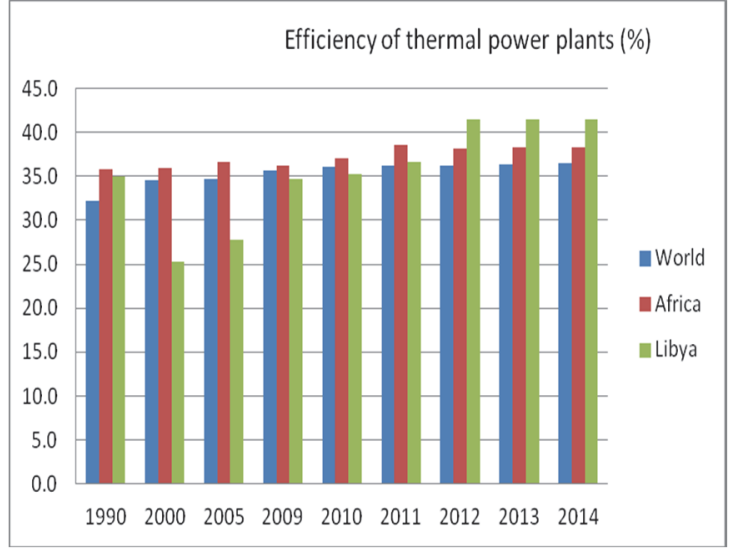

Figure 18-a. Efficiency of thermal power plants

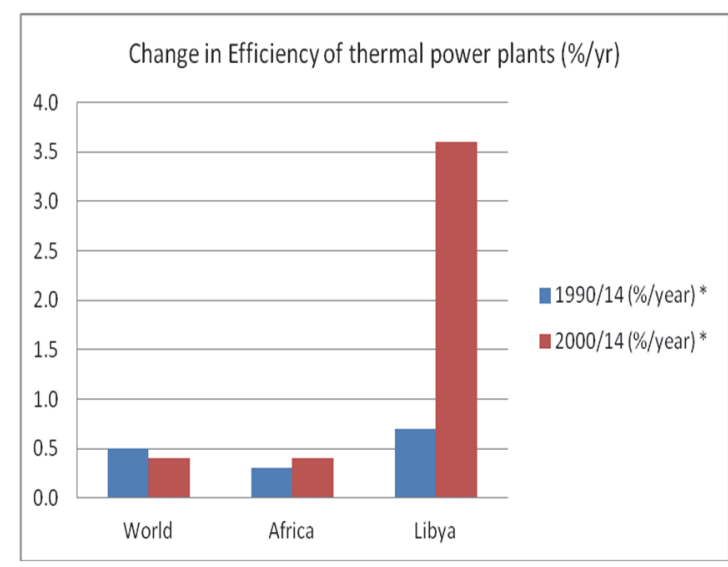

Figure 18-b. change in efficacy of thermal power plants

\subsubsection{Efficiency of Gas Fired Power Plants}

In Libya, the efficiency of gas-fired power plants had improved at a rate of $3.1 \%$ per year during the period (20002014) from $34 \%$ to $42.4 \%$. In Africa the improvement is 0.6 per year, where the efficiency of gas fired power plants was $36.7 \%$ in year 2000 and $45.6 \%$ in year 2014. The world average improvement is $0.7 \%$ per year for the same period (2000-2014), where the efficiency of gas fired power plants was $36.7 \%$ in year 2000 and $40.7 \%$ in year 2014 (WEC, 2016).

\subsubsection{Rate of Electricity Transmission and Distribution Losses}

The rate of power transmission and distribution losses, in Libya, decreased from $26 \%$ in year 2000 to $20.4 \%$ in 2014 at a rate of $(-1.8 \%)$ per year during this period. In the meantime the world average improvement is $(-0.6)$ and in Africa the losses had increased from $12.6 \%$ to $13.7 \%$ or at a rate of $0.6 \%$ per year for the same period as shown in Figure 19-a and Figure 19-b.

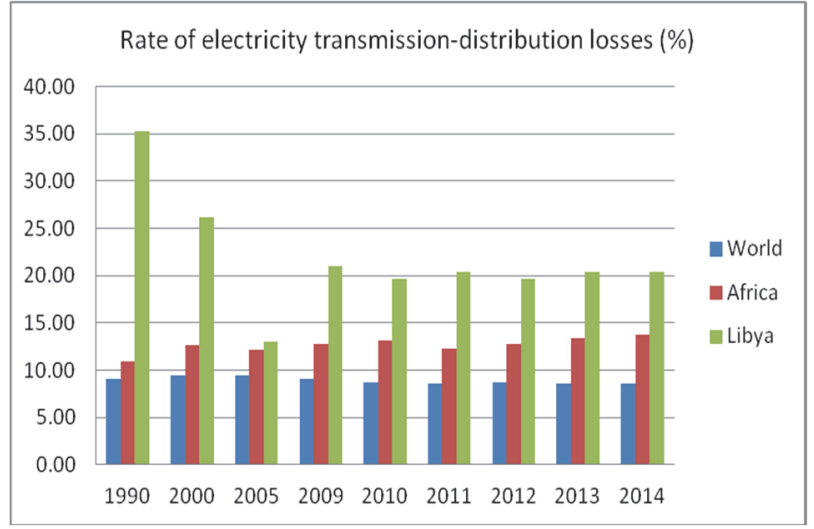

Figure 19-a. Rate of electricity T\&D losses

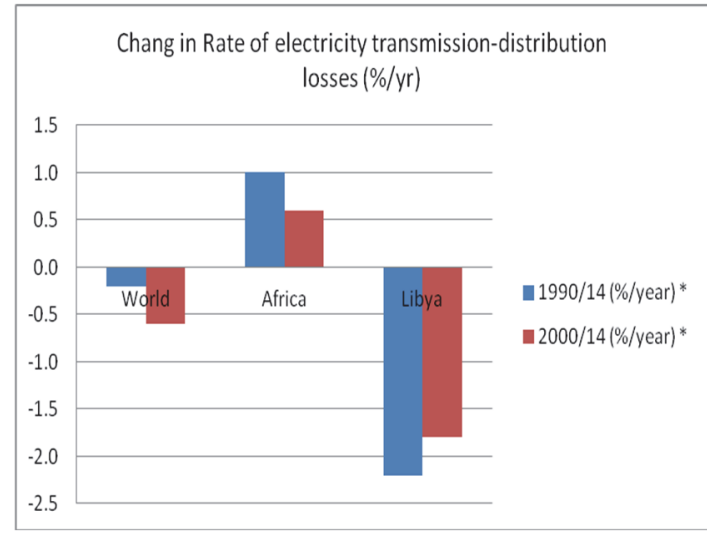

Figure 19-b. Change of electricity T\&D losses

\subsubsection{Share of efficient technologies (Combined cycle gas turbines)}

The share of combined cycle gas turbines (CCGT) in thermal installed power plants started in 2005 with a share of $24.1 \%$ and increased to $42.3 \%$ in 2014. The world average share of CCGT was $9.4 \%$ in year 2000 and grew at 
an annual rate of $5.4 \%$ per year to a $19.8 \%$ in year 2014. In Africa, the annual share rate was $13.0 \%$, which is higher than the world average, as shown in figure 20. This implies that the share of CCGT in Libya is much higher than Africa and world average.

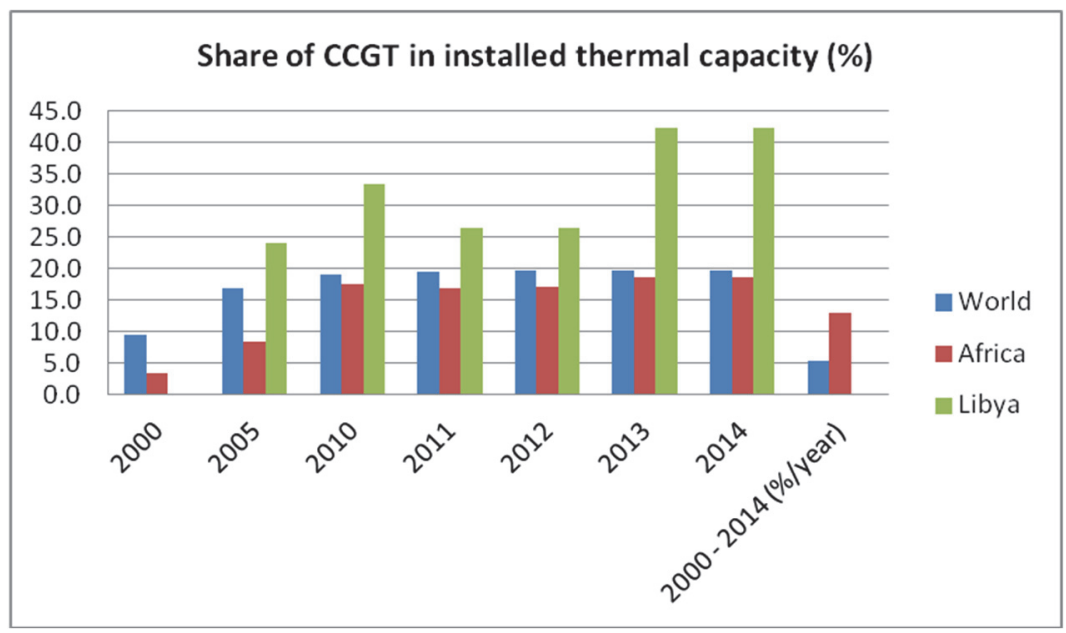

Figure 20. Share of efficient technologies

It could be concluded that the rate of improvement of thermal and gas fired power plants in Libya is high compared to Africa and the world and the improvement of the rate of power $\mathrm{T}$ and $\mathrm{D}$ losses also improved at a rate of ($1.8 \%$ ) per year during $2000-2014$, which is better than world average (-0.6\% per year) and diffenetly better than average African countries which is $(+0.6 \%$ per year). for the same period.

It could be perceived that the share of CCGT in thermal power plants in Libya even it started only in 2005 but its share in the thermal power plants is high compared to many other countries. This is due government policy to improve the the performance of power plants and reduce pollution.

\section{Energy Efficiency Policies and Measures}

Energy efficiency in addition to renewable energy can enhance an energy system. Using renewable energy sources in the national energy mix will improve primary energy intensity. Recent economic and political crisis had affected the country at different levels. Energy efficiency is a prerequisite to achieve different energy system goals such as reducing environmental pollution, which will improve health and wellbeing, providing energy access and security, reduce or lower investment in building new power plants and related infrastructure, reduce energy bills as well as create jobs. However, implementation of energy efficiency might face different barriers, which are mostly related to regulatory, legal and institutional issues, as well as economic and financial barriers. The main obstacles that could face energy efficiency programs are low prices of fossil fuel since it is subsidized by the government. The highly subsidized electricity prices could delay renewable energy and energy efficiency programs and will discourage national and international investors to invest in these programs. The other barrier is the high initial costs of these appliances (renewable and efficient appliances).

National polices should be devised to reduce or remove all barriers that could face these polices and ensures the regulation of energy efficiency programs. Development of policies and measures needs tremendous efforts and work that should be assigned to specialists in committees and working groups. Renewable Energy Authority of Libya (REAoL) is a national authority that was dispersed the task of providing and employment of energy efficiency in the country. They had prepared a National Energy Efficiency Action Plan (NEEAP). In doing so, they reviewed the world practices of energy efficiency trying to come up with best of these practices in order to implement it in Libya in a proper way. They determined and defined all barriers that are facing energy efficiency. They were also assigned to propose the required laws, regulations and incentives to be approved by the Libyan government as well as perform tasks of raising public awareness and acceptance of energy efficiency programs that would be implemented (K. Agha, 2012).

This study is proposing only highlights of main policies and measures that might be followed and guidelines to future national programs in energy efficiency. 


\section{General Aspects:}

Targets that should be set could include the following:

- Improvement of energy efficiency of different sectors by certain percentages.

- Increase the share of combined heat and power (CHP) in energy production

- Implementation of renewable energy in energy mix to improve the energy efficiency of the energy conversion of the transformation system and end use.

- Reduction of GHG

- Reduction of energy intensity

- Promote self-sufficient energy building or near zero energy buildings.

- Decrease of fossil fuel subsides by setting reasonable energy prices for fuels in transportation sector and electricity and substitute this subsidy by other regulations and laws that would promote public and investors to invest in energy efficiency and renewable energy.

- Introduction of suitable financial incentives for implementation of energy efficiency and renewable energy.

- Creation of suitable environment for the development of energy efficiency and renewable energy integration to attract national and international investors.

\section{Legal Actions:}

- Develop official and appropriate regulatory framework for electricity tariff in order to integrate renewable energy into national energy supply system and attract public and investors.

- Develop legislative and regulatory framework to invest in energy efficiency and renewable energy through national and international investors.

- Develop legislative and regulatory framework to produce fuels from renewable energy sources and related infrastructure.

- Develop legislative and regulatory framework to improve energy consumption and intensity of transportation sector.

\section{Development of Technology:}

- Development of appropriate standards and codes for energy efficiency technologies.

- Promote of energy efficiency research and development and set appropriate steps and programs for its implementation.

\section{Education, capacity building, and raising awareness:}

- Promote education courses and programs in universities and institutes in energy efficiency.

- Develop training courses and programs in energy efficiency to improve capacity building at different institutions.

- Develop dissemination system for all related information concerning benefits of energy efficiency such as economic and environmental aspects.

- Develop programs that will contribute in raising public awareness of energy savings and benefits of energy efficiency and through habitual behavior and getting efficient appliances.

- Stimulation of local market to import efficient appliances and devices and allow chances for customers to decide their preference.

\section{Discussion}

This paper concentrated on the assessment of the energy system in Libya through assessing energy intensity indicators of the transformation sector as well as end uses and the role that energy efficiency that can play in improving the energy system in general through energy measures and programs in these sectors. It proposed highlights of main policies and measures that might be taken and possibly will be a guideline to future national programs in energy efficiency.

In general, the primary energy intensity for Libya during 2000- 2014 is comparable to world average values and for Africa and the final energy, intensity has increased at only $0.7 \%$ per year during the same period. As an oil producer and exporter, the ratio of final enrgy intensity to primary energy intensity has increased. The annual increase of this ratio is (1.1\%) during (2000-2014) for Libya compared to $(0.0 \%)$ in Africa and world average of 
$(-0.2 \%)$. Also, it could be noticed that Libya has the highest emissions of $\mathrm{CO}_{2}$ per capita. This is due to high primary energy production compared to population since Libya is an oil producer and oil exporter. The $\mathrm{CO}_{2}$ intensity had increased by (3.1\%) per year in Libya during the period (2000-2014) compared to an average decrease of (-1.3) per year for the world and (-1.2) per year in Africa for the same period.

The rate of energy intensity of transport has improved on the world scale. It decreased at a rate of (-1.8\%) per year and for Africa (-0.3\%) per year for the period 2000-2014, while for Libya it has increased by $6.9 \%$ per year for the period 1990-2014 and 7.8\% per year for the period 2000-2014. This increase in Libya is due to lack of regulations and measures concerning this sector and increased number of private cars. The transport $\mathrm{CO}_{2}$ intensity for the world has decreased while in Libya it has increased from $2.3 \mathrm{tCO}_{2} / \mathrm{cap}$ to $4.06 \mathrm{tCO}_{2} / \mathrm{cap}$ at a rate of $4.7 \%$ per year for the same period (2000-2014). So suitable measures and policies should be taken towards this sector to improve its performance since it contributes to the highest share of energy consumption.

The electric energy consumption in Libya has increased during the last decade of the last century (1990-2000) but it started to decrease since 2011 . The rate of decrease in electricity consumption during $1990-2000$ is $0.8 \%$ per year while for the period 2000-2014 it is (-2.0\%) per year. The average electricity consumption of households per capita (kWh/cap) for Libya is higher than the world average and much higher than the average African countries. After the onset of hostilities in 2011, the consumption started to decrease due to electricity network as well as power generation problems. The average decrease rate of electricity consumption of households per capita is in Libya is $(-2 \%)$ per year during the period $2000-2014$, while the world average increase is $1.6 \%$ per year and in Africa at $3 \%$ per year.

Energy efficiency and energy conservation should be the primary solution to solve these problems as well as using distributed generation by renewable energy sources (PV and WECS's) instead of using fossil fuel small generators that are available right now at the market and are used by publics which contributed to noise and environment pollution.

It could be concluded that the highest share of electric energy consumption is at residential, commercial and service end use followed by street lighting. There is a good potential for energy saving at these sectors. Appropriate measures should be taken towards street lighting sector to save energy with the use of new technologies that can save up $80 \%$ and use of efficient home appliances.

The efficiency of the power plants in Libya has improved during 2000 and 2014 from $25.3 \%$ in 2000 to $41.1 \%$ in 2014, at a rate of $3.6 \%$ per year during this period. The share of combined cycle gas turbines (CCGT) in thermal installed power plants started in 2005 with a share of $24.1 \%$ and increased to $42.3 \%$ in 2014 , which is much higher than Africa and world average. In addition, it could be concluded that the rate of improvement of thermal and gas fired power plants in Libya is high compared to Africa and the world. The improvement of the rate of power $\mathrm{T}$ and $\mathrm{D}$ losses also improved at a rate of (- $1.8 \%)$ per year during $2000-2014$, which is better than world average $(-0.6 \%$ per year) and diffenetly better than average African countries which is $(+0.6 \%$ per year), for the same period. To improve the efficency of simple GT the possibilities of integrating the GT with heat recovery steam generator (HRSG) for both power generation and process heat, e.g. thermal vapor compression (TVC), desalination system (cogeneration) should be investigated, it will offer very attractive and economic solutions to Libya.

\section{References}

AFEX (2015). Arab Future Energy Index Energy Efficiency, RECREEE.

Agha, K. (2012). National Plan for developing The Renewable Energy in Libya (2013-2025), Renewable Energy Authority of Libya (REAoL), presentation, Sept. 2012.

Al-Ibrahim, A., \& Varnham, A. (2010). A review of inlet air-cooling technologies for enhancing the performance of combustion turbines in Saudi Arabia. Applied Thermal Engineering, 30, 1879-1888. https://doi.org/10.1016/j.applthermaleng.2010.04.025

Ameri, M., \& Hejazi, S. (2004). The study of capacity enhancement of the Chabahar gas turbine installation using an absorption chiller. Applied Thermal Engineering, 24, 59-68. https://doi.org/10.1016/S13594311(03)00239-4

Belzer, D. (2014). A Comprehensive System of Energy Intensity Indicators for the U.S.: Methods, Data and Key Trends, PNNL-22267, US Department of energy.

CGED (2007). Curbing Global Energy Demand Growth: The Energy Productivity Opportunity, McKinsey Global Institute.

EEPEU (2015). Energy Efficiency Policies in the European Union, lessons learned from odyssee-mure project. 
Elghawi, U., \& El-Osta, W. (2015). The alternative energy sources and technologies suitable for Libyan future energy demand mix. Int. J. Energy Technology and Policy, 11(1). https://doi.org/10.1504/IJETP.2015.069094

Elwerfelli. (2015). Elwerfelli, M., presentation, The Status of the Libyan Power System and Its Suitability for Different Generation Technologies, Seminar on Options of Electrical Power Generation in Libya, 28.01.2015

Fragkos, P., Kouvaritakis, N., \& Capros, P. (2012). Prospects for Energy Supply and demand in the Southern Mediterranean, Scenarios for 2010-30, MEDPRO Technical Report No. 22 December 2012.

GECoL (2012). General Electricity Company of Libya, annual statistics.

IEA (2008). International Energy Agency, World Energy Outlook 2008 - Global energy trends to 2030, Chapter 8.

IEA (2011). 25 Energy Efficiency Policy Recommendations.

IEA (2014a). International Energy Agency, Energy Efficiency market report.

IEA (2014b). International Energy Agency, Energy Efficiency Indicators: Fundamentals on Statistics.

IEA (2014c). International Energy Agency, Energy Efficiency Indicators- essential for policy makers.

IEA (2017). Energy Efficiency 2017, Market Report Series.

Marzouk, A., \& Hanafi, A. (2013). Thermo-Economic Analysis of Inlet Air Cooling in Gas Turbine Plants. Journal of Power Technologies, 93(2), 90-99.

Nanduri, M. (1998). An Assessment of Energy Intensity Indicators and their Role as Policy- Making Tools, Report No. 232, Simon Fraser University.

NEDP. (2006). National Energy Data Profile, Bureau of Energy and Data, Libyan National committee.

Newell, R., Stavins, R., \& Gerarden, T. (2015). Assessing the energy-efficiency gap, Working Paper 20904, MA, Jan 2015.

RCREEE (2013). Country Profile - Energy Efficiency - Libya, 2013 RCREEE. Retrieved from www.rcreee.org

RCREEE. (2012). Regional Center for Renewable Energy and Energy Efficiency, Energy Efficiency Country profile -Libya.

Sauma, E., Vera, S., Osorio, K., \& Valenzuela, D. (2016). Design of a methodology for impact assessment of energy efficiency programs: measuring in direct effect $\mathrm{s}$ in the Chilean case. Energy Efficiency, 9, 699-721.

UNEP (2011). United Nations Environment Program Development of a System of Energy Intensity Indicators for the Egyptian Economy.

UNF (2007). Realizing the Potential of Energy Efficiency, Targets, Policies, and Measures for G8 Countries.

WDI (2015). World Bank indicator. Retrieved from https://data.worldbank.org.products/wdi

WEC (2016). World Energy Council -Energy Efficiency Indicators database.

WEPEP (2013). World Energy Perspective Energy Efficiency Policies - What works and what does not, Key Messages, energy efficiency policies and trends by sector, WEC.

World atlas (2014). World atlas, the-world's largest oil-reserves-by-country. Retrieved from http://www.worldatlas.com/articles/the-world-s-largest-oil-reserves-by-country.html

World Energy Council report (2015).

\section{Copyrights}

Copyright for this article is retained by the author (s), with first publication rights granted to the journal.

This is an open-access article distributed under the terms and conditions of the Creative Commons Attribution license (http://creativecommons.org/licenses/by/4.0/). 